\title{
Law Student Learning, Storytelling and Student Device Initiatives
}

\author{
By Michael Blissenden*
}

Law student learning today needs to be student centred and involve active learning. Students need to engage with how the law develops over time in society, and how the law is made up of stories and storytelling. At the same time, modern day students are accustomed to using technology in their lives. This has resulted in a shift in higher education to tap into technology as part of engaging students with their active learning. This paper focuses on one Australian University's policy of providing students with mobile devices for their learning in law, and how the initiative can actually be interwoven with teaching pedagogy used in the classroom. Judicial reasoning is thus an art, overwhelmingly discharged in printed words and sentences. It is an art that calls on skills of narration and story-telling. The stories are normally told in words alone. Sometimes words are accompanied by pictures, drawings, or maps to make things clearer. Nowadays, judicial narrative appears in electronic form on the court's webpage shortly after delivery of judgment. Many modern academics have urged the use of storytelling as a means of giving a voice within the legal discourse to the outsider. They argue that the law is indeed replete with stories. In the classroom environment, there are a number of ways professors can utilise the pedagogical basis of storytelling. They can tell "war stories", thereby providing students insight into how the law functions. A more student-centred application of the storytelling methodology relates to the stories behind reported cases. The goal of this approach is to stimulate student interest in how the litigated case came before the courts. Modern technology has taken the act of storytelling to new heights, resulting in a range of opportunities and tools for creating, learning, teaching, and sharing knowledge in engaging ways and through innovative formats. iPads were found to be a good tool to provide instant access to rich learning materials and to Internet resources. In addition, students often used iPads for information seeking. Students found iPads to be a useful tools that increase flexibility, portability, and productivity because they are small in size, easy to use, and apps could be loaded.

Keywords: Student engagement, Digital technology, Pedagogy, Narrative Inquiry

\section{Introduction}

The above quotes illustrate the recent development of ideas concerning how the law can be viewed from a storytelling point of view. Literature indicates that judicial decision-making can be viewed as a means of storytelling, law professors can retell their experiences through war stories, and students can engage with the stories told by clients in a litigated case. Storytelling makes the law alive, makes learning the law more interesting, and makes the law more accessible through human emotions.

\footnotetext{
*Associate Professor of Law, Western Sydney University, Australia.
} 
At the same time, there have been dramatic advances in technology that the current generation of students have been exposed to and accustomed to using in their daily lives. This has also been translated to the teaching and learning environment within higher education. Technological advances, such as laptops and iPads, have been utilised in and out of the classroom to actively engage students.

A key question that the literature on the subject has not dealt with, is the interplay between the emerging pedagogy of storytelling and the use of student devices to further facilitate the learning experiences of law students. This paper will examine an initiative at Western Sydney University (previously UWS), where, in 2013, all enrolling first year students, including law students, were provided with an iPad, and how these devices were used in a classroom environment, by applying them to the storytelling pedagogy. This paper will compare that experience with second and third year law students, who did not receive an iPad, but generally used laptops.

\section{Student Learning and Storytelling}

It is generally accepted that student learning needs to be student-centred and involve active learning, both in and outside the classroom. This principle also applies to law students in higher education. Gone are the days of mere information transfer from teacher to student; there needs to be an appreciation of actively involving students in their learning process. The flipped classroom concept is one recent approach.

In that regard, there is little doubt in relation to law students that storytelling is an integral element of the law and being a lawyer. From the moment a client enters the office and recounts the basis of their particular situation to the lawyer, the makings of a story have emerged. The version of events, as described by the client, provides one side of the facts. The other story, told by the other side, will provide an alternative view of those facts. The end result may be that the legal matter goes to court, resulting in a judge constructing a story in the form of a judgment. ${ }^{1}$

It is only recently that the concepts of narrative and storytelling have been recognised as legal scholarship. ${ }^{2}$ The utilisation of the pedagogy of storytelling as a teaching and learning mechanism is becoming more common within law school classrooms. ${ }^{3}$ One particular aspect of the storytelling method that links in with the well-known legal teaching of the case method is to have students investigate the background to the litigated case and understand the human dimensions of the factual background. ${ }^{4}$ This approach not only applies the storytelling methodology to the learning and teaching of law, but also enables

\footnotetext{
${ }^{1}$ Kirby (2000).

${ }^{2}$ Krieger and Martinez (2010).

${ }^{3}$ Moran (2015).

${ }^{4}$ Blissenden (2007).
} 
students to be actively involved in their learning. In this way, the storytelling methodology facilitates a student-centred learning environment.

\section{Student use of Technology}

The dramatic changes in technology in recent years have provided immense opportunities for learning: higher education students have reported an increase in their use of mobile technology from $1.2 \%$ in 2005 to $62.7 \%$ in $2010 .{ }^{1}$ Technology is a large part of daily life, and bringing such technology into the classroom may be seen as a natural progression and not overly difficult for students to adapt to. ${ }^{2}$ Students are comfortable with technology and have been extensively exposed to a wide array of wireless machines, including smartphones, iPads, and other tablets.

However, this does not always translate to a better learning environment. Technology provides for mobile learning and allows students to engage in the educational space anytime and anywhere. Students also expect to be able to work and learn whenever they want. ${ }^{3}$ There needs to be a connection between technology, the expectation of being able to access educational material at a convenient time, and the ability to link the educational material to a sound pedagogical learning environment. The two do not automatically link together. There needs to be a well thought out approach to ensure that the educational material is formulated so that it enhances a student's ability to learn and apply it. This applies to all disciplines, not only to the study of law.

\section{Introducing iPads into Higher Education Classrooms}

In 2013, Western Sydney University (previously known as University of Western Sydney) distributed 11,000 iPads to every new student and to all academic staff to support learning and teaching innovations across the curriculum, as well as in informal learning environments. As part of this announcement, ${ }^{4}$ the University released the following statement:

"With digital technology revolutionising how we connect and interact with the world, university study should be no different," said Professor Kerri-Lee Krause, UWS Pro Vice-Chancellor (Education). "This initiative will not only readily equip our students and academic staff with mobile tools to enhance learning, it will also help them to engage with an ever-increasing online world."

\footnotetext{
${ }^{1}$ Rossing, Miller, Cecil and Stamper (2012) p. 1.

${ }^{2}$ Wardley and Mang (2015) pp. 5-6.

${ }^{3}$ Rossing, Miller, Cecil and Stamper (2012) p. 3.

${ }^{4}$ As announced on the Western Sydney Website: http://www.westernsyd ney.edu.au/newscentre/ news_centre/story_archive/december_2012/uws_deploys_ipads_to_support_it-enhanced_learning
} 
Professor Krause says the iPad initiative is just one part of a comprehensive curriculum renewal strategy at UWS, which includes implementing more flexible study options for students and a blended learning model for all UWS degrees from 2013 and beyond.

"Mobile technologies will be a key part of this strategy. We want to support our academic staff to make the most of iPads and customdesigned apps in class so that, even in the largest lecture theatre, students have access to just-for-me, just-in-time interactive learning experiences."

Professor Krause says the iPad initiative is part of a suite of innovations that involve emerging technologies to engage students within and beyond the traditional classroom, as well as making the most of work-based and community-based learning to bring higher education to life.

"Our students tell us they want more flexible ways to learn. They have paid work and family commitments, yet they value the support offered by a campus-based experience. To increase flexible access to 'learning on the go', our students will be able to learn using more online and web-streamed material while at the same time benefiting from 'flipped' approaches to traditional university teaching that emphasise interactive and collaborative face-to-face learning.

"We are also expanding the range of study modes, to include more intensive and weekend classes to give our students more flexibility and choice.

"The iPad initiative is just one part of our broader, four-year Blended Learning Strategy to embrace emerging technologies and other modes of learning as a way to complement our face-to-face teaching, which will of course remain core to UWS."

With six campuses geographically spread across the expansive region of Greater Western Sydney-each offering free wireless internet to students- the UWS iPad initiative also ensures that all new students can connect with the University via Wi-Fi at any time of day.

"The University's analytics also show that our e-learning system is accessed 24 hours a day, seven days a week," says Professor Krause.

"So, not only do we expect this initiative to be useful for students on campus as part of their university studies, but we expect it will also greatly enable our first-year students to engage with the University and their learning when and where they choose."

Some specific observations can be made concerning this extensive and free iPad initiative, which were also provided to academic staff. First, it recognises that, with digital technology revolutionising the way students interact with the world, it makes sense for technology to be used in an educational context. Second, it reflects the realisation that mobile technologies will assist students 
in engaging with an ever increasing online world. Third, the University did not consider any other options besides issuing iPads to students. There was no consideration given to providing students with a laptop. This is in line with the desire for students to be able to access relevant apps on their iPad. Fourth, the UWS iPad initiative enables students to access University materials via Wi-Fi any time of the day. This means that the iPads issued do not have network access, but instead, they rely on Wi-Fi for internet connectivity. Finally, the iPad initiative is directed to first year students only. This means that second or third year students were not provided with an iPad.

It should also be noted that UWS has Wi-Fi connectivity on all six campuses, and this enables students to access the internet and UWS intranet. On that basis, all first year students are able to use their iPads to access educational material on campus. However, those students are only able to access the internet off campus if Wi-Fi connectivity is available where they are at the time the student wants to access their educational material.

The only aspect relates to the fact that other students were not provided with an iPad. In general, this would not cause any issue as students in first year would not be in classes with second and third year students. However, it may cause a problem for those staff that are teaching first year classes and also second or third year classes. It may need adjustment on behalf of the teacher in terms of in-class activities for those students who do not have iPads or other technological devices. This aspect will be discussed in more detail in the following section.

\section{Teaching to First Year Law Students with iPads and Later Year Students Without iPads}

\section{First Year Law Students}

It must be noted that the iPad initiative at UWS was specifically designed to assist first year students only. This means that academic staff teaching first year students will be designing educational activities around the use of iPad applications, and utilizing such applications within the classroom, as Wi-Fi is available within those classrooms. This raises the question of which applications can be used, as not all applications are free. The academic staff member must make a decision as to whether it is appropriate to request students to download apps that are a cost to the student, or just restrict learning and teaching to those apps that can be downloaded for free. This raises an equity issue that needs to be addressed at a university level.

The UWS initiative encouraged the use of iPads, relevant apps, and internet access for learning purposes. However, iPads are not generally receptive to note taking, and recent research indicates that students tend to stop using their iPads after a few weeks, due to the difficulty of taking notes. ${ }^{1}$ There is the Evernote app, which allows students to take notes, but it is not as user-

\footnotetext{
${ }^{1}$ Fischman and Keller (2011).
} 
friendly as being able to type via laptop. This was also a factor in the UWS initiative, where first year students were trying to come to grips with the university environment, coping with a different learning environment, and, specifically, using iPad technology for learning. First year university students have, in fact, been used to technology, but it may be more in the form of laptops rather than iPad tablet technology, and this may be a factor in being able to utilise the technology for learning and teaching purposes. Some studies have also confirmed that the iPad trials at Stanford and the University of Notre Dame were not successful as many students were uncomfortable with the technology and were more used to traditional technologies such as laptops. ${ }^{1}$

This was also the experience in relation to the iPad initiative for first year law students at UWS. Students were happy to receive an iPad and realised that the iPad was going to be used in the classroom as an integral element of their learning. Academic staff were also committed to the use of the iPad for teaching purposes, and this was clearly set out in the respective learning guides for each law unit. The interactive learning exercises included having students access, download, and use relevant legal apps in relation to preset problems. One particular app used was the "Austlii" app, which provides students access to Australian legislation and court decisions. Another very useful app for law students was the "AGLC Ref" app, which provided students with access to proper referencing styles for assignments and research papers. These materials provide opportunities for both academic staff and students to engage with introductory legal topics and concepts. The problems encountered related not to the availability of very useful legal information, but to the fact that students wanted to engage with the teacher and take relevant notes to complement their knowledge base. This was not easy to do with the iPad, and led to students using other mobile devices, such as laptops, to accommodate this learning need. The end result was some students bringing their laptops - instead of their iPad-to class.

The use of mobile devices within the classroom provided an excellent opportunity for the storytelling pedagogy to be introduced to first year law students. Students were able to use free apps, such as "Explain Everything," to create their own story about their experiences with the law, and to share such stories with their classmates. The access to the internet, and, thus, access to unlimited material enabled students to investigate the background of cases and present their findings to the remainder of the class. Students can use either the app "Bamboo Paper" and/or "iMovie" to create a review of their investigatory process and describe to their classmates how litigation between the parties arose, and the human emotions and attitudes of the relevant parties. Students could share their findings with their classmates by loading them on the shared UWS intranet. The only requirement was access to $\mathrm{Wi}-\mathrm{Fi}$, which is available at UWS throughout all classrooms. In short, first year students were able to come to grips with the human aspect relating to the story behind the litigating parties and enabled to understand how the law operates in a practical manner.

\footnotetext{
${ }^{1}$ Weider (2011).
} 


\section{Second and Third Year Law Students}

Because iPads were only issued to first year students, second and third year law students either had to bring their own devices, or not have a device at all. This made it challenging for both students and academic staff members. Interactive classroom activities were potentially affected unless the teacher was well prepared and structured appropriate classroom activities. In short, if the teacher set out the relevant requirements for the upcoming class, then students were in a good position to be able to come to class and access any online material that was being utilised. The difference, though, was that with second and third year students, the teacher needed to ensure that online educational activities were designed to accommodate the various devices that students would bring to class - be it a laptop, smart phone, or even an iPad.

Any mobile device used by second or third year law students provided an ideal opportunity to enhance the storytelling methodology by the academic teacher. Students are already exposed to reported cases and legislative processes in first year, so the opportunity arises in the later years to build upon the storytelling methodology. The storytelling method only requires that students have access to the internet, via Wi-Fi connectivity, and this was readily available to students in UWS classrooms. So, on that basis, there was no need for students to actually have an iPad; they just needed access to any mobile device. There was no need to access any specific applications, but, instead, the opportunity arose to advance engaged active learning. For example, the use of the flipped classroom approach, allowing students to use technology and the internet to provide learning experience with students driving that learning in the classroom.

The end result of this teaching experience was that the availability of a mobile device, with Wi-Fi connectivity, was the key to structuring appropriate online activities for instructional design. Students needed to be aware of the potential of mobile devices for educational purposes, but they also need to be guided by their teachers as to how mobile devices are to be utilised within the classroom. If students only had access to iPads, then the teacher would need to be selective with what apps were to be used, and how to link them to the content for the particular unit of study. If students had other mobile devices, then the educational activities could be structured around how to use such devices, and that might also involve facilitating note taking. For those teachers wishing to investigate and apply the storytelling methodology, it did not matter which mobile device was being used, as long as internet access was available.

The storytelling pedagogy is only dependent on having a technological device and access to the internet, either within or outside the classroom. It makes no difference which particular technological device is being used by the student. The underlying rationale for the pedagogy rests in students actively investigating the background of a case and then formulating their findings for presentation to the class. The interaction between technology and the learning methodology of storytelling is very flexible. Students are used to life with technology, so with the move by universities to utilise technology in an 
educational sense fits perfectly with the concept of storytelling from student stories, teacher war stories, and stories of the litigating parties behind the cases.

\section{Student Device Initiative at Western Sydney University}

In 2016, Western Sydney University took the approach that technological devices are central to the learning and teaching for students. Deputy Vice Chancellor Denise Kirkpatrick noted in a statement on January 8, 2016 ${ }^{1}$ : "Several years ago Western Sydney University became one of the first universities to provide devices (iPads) to students as part of its flexible learning program. The 2016 program takes that a step further as the University works with industry leading technology partners such as Microsoft, to determine the most suitable device for each of our courses."

The 2016 program revolves around the Student Device Initiative whereby a new device (either an iPad, Tablet or Windows Laptop) will be provided to all new commencing undergraduate students based on the course they are undertaking in 2016. The mobile technology will enable students to engage with the growing number of online services-which will include online lectures, live web streaming of lectures, apps, and other tools that aim to provide the best possible learning and university experience.

In the case of the law course, students are still receiving iPads in 2016, so there is no change from the previous arrangement. As a comparison, students enrolled in a business course are now receiving laptops. Again, the device strategy is only for first year students and students are unable to choose which device they will receive. The decision as to which device to provide to students was made by each school, in conjunction with the relevant academic staff. As discussed earlier, in the approach taken in the storytelling methodology for law students, there is no difference as to which device a student has to bring to class, so this provides a rationale as to maintaining the iPad strategy.

\section{Conclusion}

The 2013 iPad initiative was a bold move by Western Sydney University. The underlying goal was to link a technological device-an iPad-with relevant educational apps for learning and teaching purposes. The general consensus from students was that this was a positive approach and that it motivated students. Of course, it is clear that having an iPad in class with WiFi internet access could be viewed as a distraction to students, as it is easy for them to then $\log$ onto their social media sites. Academic staff must be aware of this issue and ensure that relevant in-class activities kept law students active. Again, the storytelling methodology facilitates law students being active throughout the class. A structured series of online activities keep law students

${ }^{1}$ http://news.microsoft.com/en-au/2016/01/06/surface-reshapes-western-sydney-university-fle xible-learning-environment/ 
busy locating information on the internet, using relevant apps to collate, and then present their findings.

The move in 2016 by Western Sydney University to widen the provision of a device for students to include other technological devices acknowledges that different disciplines may need different approaches for their learning and teaching. It also illustrates that there is a need to work with the relevant hardware providers and build a relationship. For example, for those receiving the Microsoft Surface 3 device, there is recognition that Microsoft will support the implementation of the program and enhance educational uses so as to allow students to create, collaborate, and analyse problems since the device functions as full personal computer.

There is one aspect that needs a word of caution. It relates to law teachers who also have to implement the learning and teaching strategy. Most law teachers have used the lecture method, problem-based questions, and case studies to teach the law for many years. With the advent of technology, it does not mean that there is an easy transformation to an online and interactive teaching methodology. Support needs to be given to such teachers to ensure that they are also able to move with confidence into this brave new world of higher education learning and teaching. With that support, the future for both student and teacher in legal education looks promising.

\section{References}

Blissenden, M.W. (2007). Using Storytelling as a Teaching Model in a Law School: The Experience in an Australian Context', The Law Teacher 41(3):260-74.

Blissenden, M.W. (2015). 'Teaching Undergraduate Law Students in the $21^{\text {st }}$ Century - Pedagogy in a Technological Era', Athens Journal of Law 1(3):213-220.

Heerey, P. (2000). 'Storytelling, Postmodernism and the Law', Australian Law Journal 74(10):681-691.

Kirby, M. (2000). 'Literature in Australian Judicial Reasoning' Address to the $34^{\text {th }}$ Annual Dinner of the Foundation for Australian Literacy Studies, James Cook University, Townsville, Queensland, 16 October 2000.

Krieger, S. and S. Martinez (2010). 'A Tale of Election Day2008: Teaching Storytelling through Repeated Experiences', The Journal of the Legal Writing Institute 16:117-162.

Lal, S., Donnelly, C., and J. Shin (2015). 'Digital Storytelling: An Innovative Tool for Practice, Education, and Research', Occupational Therapy in Health Care 29:5462.

Moran, J. (2015). Families, Law, and Literature: The Story of a Course on Storytelling', University of San Francisco Law Review 49:1-56.

Nguyen, L., Barton, S.M. and L.T. Nguyen (2015). 'iPads in Higher Education - Hype and Hope', British Journal of Educational Technology 46(1):190-203. doi: $10.1111 /$ bjet.12137

Rossing, J., Miller, W., Cecil, A. and S. Stamper (2012). 'iLearning: The future of Higher Education? Student Perceptions on Learning with Mobile Tablets', Journal of the Scholarship of Teaching and Learning 12(2):1-26. 
Wardley, L. and C. Mang (2015). 'Student observations: Introducing iPads into University Classrooms', Educational Information Technology 1-18.

Weider, B. (2011).'iPads Could Hinder Teaching, Professors Say', 57(28) Chronicle of Higher Education 57(28):A22-A23. 